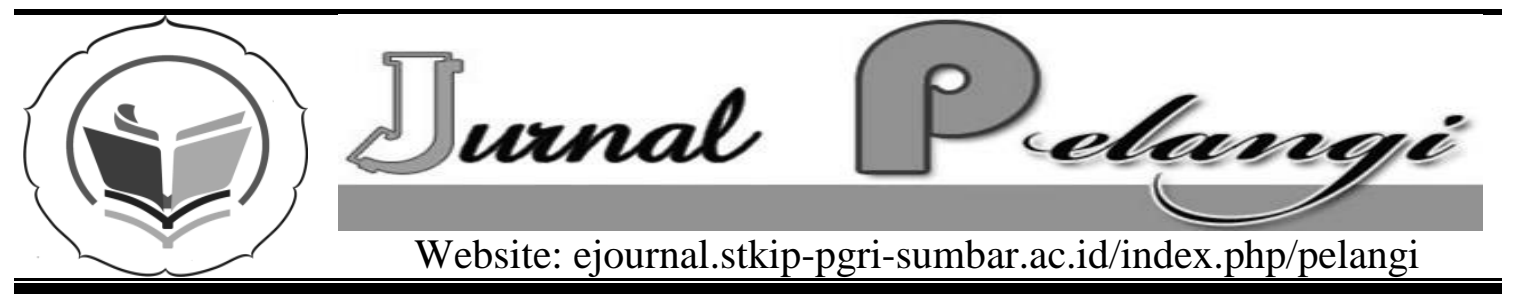

\title{
PENERAPAN PENDEKATAN TEMATIK UNTUK MENINGKATKAN KETERAMPILAN BERBICARA SISWA KELAS I SD
}

\author{
Welnahayati \\ SD Negeri 05 Malabur \\ welnahayati@yahoo.co.id
}

\section{INFO ARTIKEL}

Diterima:

1 Desember 2015

Direview:

12 Desember 2015

Disetujui:

22 Desember 2015

Kata Kunci:

Pembelajaran tematik, Ketrampilan berbicara
Keywords:

Thematic Learning, SpeakingSkill

\begin{abstract}
Abstrak
Permasalahan yang dihadapi adalah pembelajaran tematik dalam meningkatkan keterampilan berbicara siswa di kelas I masih menggunakan pendekatan yang lama dimana siswa menerima saja materi pelajaran tanpa menemukan sendiri sehingga mengakibatkan siswa pasif dan tidak serius dalam belajar. Tujuan penelitian ini untuk mendeskripsikan Penerapan Pendekatan Tematik Untuk Meningkatkan Keterampilan Berbicara Bagi Siswa Kelas I SD Negeri 05 Malabur Kecamatan Ampek Nagari. Jenis penelitian ini adalah Penelitian Tindakan Kelas (classroom action research). Penelitian ini menggunakan pendekatan kuantitatif sederhana. Data penelitian ini berupa informasi tentang proses dan data hasil tindakan yang diperoleh dari hasil pengamatan, hasil tes. Sumber data adalah proses pelaksanaan Pembelajaran Tematik dalam Meningkatkan Keterampilan Berbicara di Kelas I SD Negeri 05 Malabur Kecamatan Ampek Nagari. Subjek penelitian adalah siswa kelas I yang berjumlah 26 orang. Hasil penelitian yang dianalisis berdasarkan data kualitatif dan kuantitatif, menunjukkan bahwa pada siklus I nilai rata-rata siswa 72.6 dan meningkat pada siklus II dengan nilai rata-rata 78.8 .
\end{abstract}

\section{Abstract}

The background of the research is that the thematic learning used to improve the speaking skill in the class 1 is old approach in which the students only take the lesson without finding out by themselves, so that they are passive and unfocused to study. The purpose of the research is to describe the applying a thematic approach to improve the speaking skill for students class 1 Elementary School 05 Malabur Kecamatan 
Ampek Nagari. The type of the research is Classroom Action Research (CAR). It used a simple quantitative approach. The data were information about the process, data action result from the observation, and test result. The source of data were the process of implementing the thematic learning in improving the the speaking skill for students class 1 Elementary School 05 Malabur Kecamatan Ampek Nagari. The subject of the research were the students of class 1, i.e. 26 students. The research results were analyzed based on the qualitative and quantitative data in which it shows that in the first cycle, the student's average score is 72,6 and it keeps improving in the second cycle, i.e 78,8.

\section{PENDAHULUAN}

Pendidikan merupakan salah satu faktor penentu dalam upaya meningkatkan kualitas sumber daya manusia, Pendidikan selalu mengupayakan kehidupan manusia ke arah yang lebih baik dan diperlukan untuk kehidupan di masa akan datang. Pendidikan berperan penting dalam rangka mencerdaskan kehidupan bangsa.

Sekolah Dasar merupakan sebuah jenjang pendidikan yang diikuti oleh siswa dengan rentang usia normal 6 sampai dengan 12 tahun. Pada masa ini anak sudah mulai berfikir logis, akibat dari adanya kegiatan anak yang telah mampu memanipulasi benda-benda konkrit. Begitu pula dalam kegiatan kesehariannya baik di lingkungan sekolah maupun rumah. Ketertarikan siswa akan benda-benda pada lingkungannya seiring dengan masa operasi konkrit, anak lebih cenderung menginginkan untuk bermain dari pada belajar secara formal. Hal ini menyebabkan beberapa anak malas untuk belajar dan lebih tertarik dengan benda-benda yang sesuai dengan masanya.
Salah satu komponen yang sangat penting dalam dunia pendidikan adalah guru, guru merupakan ujung tombak pendidikan. Guru mempunyai peranan yang sangat besar dan strategis, karena gurulah yang berada di barisan paling depan dalam pelaksanaan pendidikan. Guru langsung berhadapan dengan siswa dalam kegiatan pembelajaran yang di dalamnya mencakup kegiatan pentransferan ilmu pengetahuan.

Keberhasilan dalam proses pembelajaran yang dilakukan guru di dalam kelas ialah menggunakan media pembelajaran, sebab kegiatan belajar mengajar pada hakekatnya adalah komunikasi. Dalam proses komunikasi ini guru berperan sebagai komunikator yang akan menyampaikan pesan kepada siswa. Agar pesan itu dapat diterima dengan baik oleh siswa, maka perlu suatu media.

Pembelajaran tematik sesuai dengan tahap perkembangan siswa, karakteristik cara siswa belajar, konsep belajar dan pembelajaran bermakna. Pembelajaran pada kelas awal Sekolah Dasar (SD) lebih sesuai jika di kelola melalui pendekatan tematik, karena pada umumnya dalam tahap ini siswa melihat 
segala sesuatu itu sebagai kesatuan yang utuh (holistik). Di mana perkembangan pisiknya seiring dengan perkembangan mental, sosial dan emosional.

Salah satu pendekatan yang membuat pembelajaran lebih bermakna adalah pendekatan tematik. Menurut Hilda (2006:1) "Pendekatan tematik adalah pembelajaran terpadu yang menggunakan tema dalam pembelajaran sehingga dapat memberikan pengalaman bermakna pada siswa." Sedangkan Christine (1990:39) menyatakan pembelajaran tematik adalah pembelajaran terpadu (Integrated) yang dapat dilaksanakan pada semua mata pelajaran. Dalam pembelajaran terpadu untuk mata pelajaran bahasa tidak ada pelajaran khusus untuk kegiatan menyimak, berbicara, membaca, dan menulis. Artinya pembelajaran menyimak, berbicara, membaca, dan menulis dilaksanakan terpadu dengan tema sebagai alat pemersatunya.

Pembelajaran pada hakekatnya adalah suatu proses interaksi antar siswa dengan siswa, siswa dengan sumber belajar dan siswa dengan pendidik. Kegiatan pembelajaran ini akan menjadi bermakna bagi siswa jika dilakukan dalam lingkungan yang nyaman dan memberikan rasa aman bagi siswa. Proses belajar bersifat individual dan kontekstual, artinya proses belajar terjadi dalam diri individu sesuai dengan perkembangan dan lingkungan siswa.

Belajar akan lebih bermakna jika siswa mengalami langsung apa yang dipelajarinya dengan mengaktifkan lebih banyak indera dari pada hanya mendengarkan guru menjelaskan. Salah satu pembelajaran yang bermakna yaitu dengan menggunakan pendekatan tematik.

Pembelajaran tematik merupakan implementasi dari Kurikulum Tingkat Satuan Pendidikan (KTSP). Menurut Karli (2006:1) "Pendekatan tematik adalah pembelajaran terpadu yang menggunakan tema dalam pembelajaran sehingga dapat memberikan pengalaman bermakna pada siswa." Sedangkan Papas (1990:39) menyatakan pembelajaran tematik adalah pembelajaran terpadu (Integrated) yang dapat dilaksanakan pada semua mata pelajaran. Dalam pembelajaran terpadu untuk mata pelajaran bahasa tidak ada pelajaran khusus untuk kegiatan menyimak, berbicara, membaca, dan menulis. Artinya pembelajaran menyimak, berbicara, membaca, dan menulis dilaksanakan terpadu dengan tema sebagai alat pemersatunya.

Menurut Depdiknas (2006:97) "Pendekatan tematik merupakan pembelajaran terpadu yang menggunakan tema untuk mengaitkan beberapa mata pelajaran sehingga dapat memberikan pengalaman yang bermakna kepada siswa". Keterpaduan dalam pembelajaran ini dapat dilihat dari aspek proses atau waktu, aspek kurikulum, dan aspek belajar mengajar.

Papas (1990:105) dan Karli (2006:95) menyatakan pembelajaran pada kelas awal Sekolah Dasar (SD) lebih sesuai jika di kelola melalui pendekatan tematik, karena pada umumnya dalam tahap ini siswa melihat segala sesuatu itu sebagai kesatuan yang utuh (holistik). Di mana perkembangan pisiknya seiring dengan perkembangan mental, sosial dan emosional. 
Berdasarkan pendapat di atas yang dimaksud dengan pendekatan tematik adalah suatu pendekatan pembelajaran yang beranjak dari suatu tema untuk mengaitkan beberapa mata pelajaran tertentu dan konsep yang lain secara spontan atau direncanakan dengan memberikan pengalaman bermakna kepada siswa, sehingga siswa dapat belajar dengan aktif dan efesien.

Sebagai suatu proses, pembelajaran tematik memiliki karakteristikkarakteristik tematik. Menurut Depdiknas (2006:98) menyatakan bahwa: 1) Berpusat kepada siswa; 2) Memberikan pengalaman langsung; 3) Pemisahan mata pelajaran tidak begitu jelas; 4) Menyajikan konsep dari berbagai mata pelajaran; 5) Bersifat fleksibel; 6) Hasil pembelajaran sesuai dengan minat dan kebutuhan siswa; 7) Menggunakan prinsip belajar sambil bermain dan menyenangkan. Sehingga siswa yang berada di kelas rendah SD adalah siswa yang berada pada rentangan usia dini. Masa usia dini ini merupakan masa yang pendek tetapi merupakan masa yang sangat penting bagi kehidupan seseorang. Oleh karena itu, pada masa ini seluruh potensi yang dimiliki siswa perlu didorong sehingga akan berkembang secara optimal.

$$
\text { Menurut Depdikbud }
$$

Pembelajaran Bahasa Indonesia di kelas I SD diarahkan untuk mempertajam kepekaan perasaan siswa. Siswa tidak hanya diharapkan mampu memahami informasi yang disampaikan secara langsung, melainkan juga yang disampaikan secara terselubung atau secara tidak langsung. Pembelajaran bahasa mencakup aspek menyimak, berbicara, membaca, dan menulis. Keempat aspek tersebut sebaiknya mendapat porsi yang seimbang. Dalam pelaksanaannya dilakukan secara terpadu.

Konteks atau tema digunakan untuk memadukan pembelajaran serta pengembangan dan perluasan perbendaharaan kata siswa dan pemersatu kegiatan berbahasa (menyimak, berbicara, membaca, dan menulis). Tujuannya adalah agar pembelajaran bahasa berlangsung dalam suasana kebahasaan yang wajar, tidak disajikan dalam kalimat-kalimat yang lepas.

Bahan pelajaran kebahasaan mencakup lafal, ejaan dan tanda baca, kosakata, struktur, paragraf, dan wacana. Lafal yang baik dan wajar perlu diperkenalkan sejak dini, termasuk cara pengucapan yang jelas dan intonasi yang wajar sesuai dengan situasi kebahasaan. Ejaan dan tanda baca diajarkan tahap demi tahap untuk membiasakan siswa menggunakannya baik kegiatan membaca maupun menulis dengan tingkat ketelitian dan pemahaman yang baik.

Jadi pembelajaran Bahasa Indonesia di SD mencakup empat aspek yaitu: menyimak, berbicara, membaca, dan menulis dengan menggunakan tema tujuanya adalah agar pembelajaran bahasa berlangsung dalam suasana kebahasaan yang wajar, tidak disajikan dalam kalimat-kalimat yang lepas.

Menurut Tarigan, dkk (1986:8) menyimak adalah "Suatu proses kegiatan menyimak lambang-lambang lisan dengan penuh perhatian, pemahaman, apresiasi, serta interpretasi untuk 
memperoleh informasi, menangkap isi atau pesan serta memahami makna komunikasi yang telah disampaikan oleh sang pembicara melalui ujaran atau bahasa lisan." Menyimak mempunyai peranan penting karena dengan menyimak siswa dapat menambah ilmu, menerima dan menghargai pendapat orang lain.

Menurut Logam (dalam Santosa, 2004:24) "Menyimak dapat dipandang sebagai suatu sarana, sebagai keterampilan, sebagai seni, sebagai proses, sebagai respon atau sebagai pengalaman kreatif." Menyimak dikatakan sebagai suatu sarana sebab adanya kegiatan yang dilakukan seseorang pada waktu menyimak yang harus melalui tahap mendengar bunyibunyi yang telah dikenalnya.

Jadi dari beberapa pendapat di atas dapat disimpulkan menyimak adalah suatu proses yang mencakup kegiatan mendengarkan bunyi bahasa, mengidentifikasi yang terkandung di dalamnya. Menyimak melibatkan pendengaran, penglihatan, penghayatan, ingatan, dan pengertian.Tujuan pembelajaran menyimak melatih siswa memahami bahasa lisan. Oleh sebab itu, pemilihan bahan pembelajaran menyimak harus disesuaikan dengan karakteristik siswa SD. Penyimak yang baik adalah penyimak berencana. Salah satu butir dari perencanaan itu ada alasan tertentu mengapa yang bersangkutan menyimak. Alasan inilah yang kita sebut sebagai tujuan menyimak. Menyimak pada hakikatnya adalah mendengarkan dan memahami isi bahan simakan, karena itu dapat disimpulkan bahwa tujuan utama menyimak adalah menangkap, memahami, atau menghayati pesan, ide, gagasan yang tersirat dalam bahan simakkan.

Menurut Abbas (2006:83) berbicara dapat di artikan "Sebagai kemampuan mengucapkan bunyi-bunyi bahasa untuk mengekpresikan atau menyampaikan pikiran, gagasan atau perasaan secara lisan". Berbicara merupakan kegiatan menyampaikan pesan melalui bahasa lisan. Dengan demikian, berbicara pada hakikatnya merupakan suatu proses berkomunikasi dengan mempergunakan suara yang dihasilkan oleh alat ucap manusia yang di dalamnya terjadi pemindahan pesan dari suatu sumber ke tempat yang lain. Sedangkan menurut Agung (2008:3) mendengar adalah "Proses kegiatan menerima bunyibunyian yang dilakukan tanpa sengaja atau secara kebetulan saja.

Agung (2008:1) mengatakan berbicara adalah "Merupakan suatu aktivitas kehidupan manusia normal yang sangat penting, karena dengan berbicara kita dapat berkomunikasi antara sesama manusia, menyatakan pendapat, menyampaikan maksud, dan pesan, mengungkapkan perasaan dalam segala kondisi emosional". Keterampilan berbicara pada dasarnya harus memiliki oleh semua orang yang didalam kegiatannya membutuhkan komunikasi, baik yang sifatnya satu arah maupun yang timbal balik ataupun keduanya.

Jadi dapat disimpulkan bahwa berbicara adalah sebagai suatu penyampaian maksud (ide, pikiran, dan isi hati) seseorang kepada orang lain dengan menggunakan bahasa lisan, sehingga maksud tersebut mudah dipahami orang lain. 
Tujuan utama pembelajaran berbicara di SD melatih siswa dapat berbicara dalam bahasa Indonesia dengan baik dan benar. Saat guru memberikan pembelajaran berbicara ada beberapa hal yang harus diperhatikan.

Menurut Rahim (2006:2), membaca pada hakekatnya adalah suatu yang rumit yang melibatkan banyak hal, tidak hanya sekedar melafalkan tulisan tetapi juga melibatkan aktivitas visual, berfikir psikolinguistik, dan metakognitif, sebagai proses visual, membaca merupakan proses menterjemahkan simbol tulisan (huruf) ke dalam kata-kata lisan." Selanjutnya dipertegas oleh Crawley (dalam Rahim, 2006:2) sebagai suatu proses berpikir, membaca mencakup aktivitas pengenalan kata, pemahaman literal, interpretasi, membaca kritis, dan pemahamn kreatif. Pengenalan kata dapat berupa aktivitas membaca kata-kata dengan menggunakan kamus.

Menurut Klein, dkk (dalam Rahim, 2006:3) mengemukakan bahwa definisi membaca mencakup: "1) membaca merupakan suatu proses; 2) membaca adalah strategis; dan 3) membaca merupakan interaktif." Senada dengan itu, Zainuddin (1992:124) mengemukakan membaca dalam arti sederhana adalah "Menyuarakan bunyi atau deretan bunyi yang berupa kata dan kalimat."

Anderson (dalam Akhaidah, 1991:22) membaca merupakan suatu kesatuan kegiatan terpadu yang mencakup beberapa kegiatan, seperti mengenali huruf dan kata-kata, menghubungkannya dengan bunyi serta menarik kesimpulan mengenai maksud bacaan."

Berdasarkan beberapa pendapat di atas, dapat disimpulkan bahwa membaca adalah proses interaksi memahami lambang bahasa melalui berbagai strategi untuk memahami makna dari yang tertulis.

Menurut Refandi (2008:2) "Menulis menurunkan atau melukiskan lambanglambamg grafik yang mengambarkan suatu bahasa yang dipahami oleh seseorang, sehingga orang lain dapat membaca lambang-lambang grafik tersebut kalau mereka memahami bahasa dan gambar grafik itu"

Keterampilan menulis merupakan salah satu keterampilan berbahasa yang menjadi tujuan setiap pengajaran bahasa di sekolah. Sedangkan menurut Tarigan, dkk (1986:21) "Menulis merupakan atau melukiskan lambang-lambang grafik yang menggambarkan suatu bahasa yang paham oleh seseorang sehingga orang lain dapat membaca lambang-lambang seperti grafik tersebut".

Dari berbagai pendapat yang telah dikemukakan para ahli diatas dapat ditarik suatu kesimpulan bahwa menulis adalah suatu proses menyampaikan pesan, ide dan gagasan dengan menggunakan bahasa tulis.

Implementasi pembelajaran tematik di Sekolah Dasar mempunyai berbagai implikasi. Menurut Depdiknas (2006:100) yaitu : 1) Implikasi bagi guru; 2) Implikasi bagi siswa; 3) Implikasii terhadap sarana, prasarana, sumber belajar, dan media; 4) Implikasi terhadap pengaturan ruangan; 5) Implikasi terhadap pemilihan metode. 
Implikasi bagi guru, pembelajaran tematik ini memerlukan guru yang kreatif baik dalam menyiapkan kegiatan pembelajaran bagi siswa. Selain itu juga berimplikasi dalam memilih kompetensi serta mengaturnya agar pembelajaran menjadi lebih bermakna, menarik, menyenangkan dan utuh.

Implikasi bagi siswa yaitu siswa harus siap mengikuti kegiatan pembelajaran yang dalam pelaksanaannya dimungkinkan untuk bekerja baik secara individual, pasangan, kelompok kecil ataupun klasikal, dan siswa siap mengikuti kegiatan pembelajaran yang bervariasi secara aktif misalnya melakukan diskusi kelompok, mengadakan penelitian sederhana dan pemecahan masalah.

Implikasi terhadap sarana, prasarana, sumber belajar dan media yaitu pembelajaran tematik menekankan pada siswa baik secara individu maupun kelompok untuk aktif mencari, menggali dan menemukan konsep serta perinsipprinsip holistik dan otentik. Oleh karena itu, dalam pelaksanaannya memerlukan berbagai sarana dan prasarana belajar. Pembelajaran ini perlu memanfaatkan berbagai sumber belajar baik yang sifatnya didesain secara khusus untuk keperluan pelaksanaan pembelajaran, maupun sumber belajar yang tersedia di lingkungan yang dapat dimanfaatkan. Pembelajaran ini juga perlu mengoptimalkan penggunaan media pembelajaran yang bervariasi sehingga akan membantu siswa dalam memahami konsep-konsep abstrak. Penerapan pembelajaran tematik di Sekolah Dasar masih dapat menggunakan buku ajar yang sudah ada saat ini untuk masing- masing pembelajaran dan dimungkinkan pula untuk menggunakan buku suplemen khusus yang memuat bahan ajar yang terintegrasi.

Implikasi terhadap pengaturan ruangan dalam pembelajaran tematik perlu dilakukan agar suasana belajar menyenangkan. Pengaturan ruangan tersebut meliputi ruang perlu ditata disesuaikan dengan tema yang sedang dilaksanakan. Susunan bangku peserta didik dapat berubah-ubah disesuaikan dengan keperluan pembelajaran yang sedang berlangsung. Siswa tidak selalu duduk di kursi tetapi dapat duduk di tikar atau karpet. Kegiatan hendaknya bervariasi dan dapat dilaksanakan baik di dalam kelas maupun di dalam kelas. Dinding kelas dapat dimanfaatkan untuk memajang hasil karya siswa serta dimanfaatkan sebagai sumber belajar. Alat sarana dan sumber belajar hendaknya dikelola sehingga memudahkan siswa utnuk menggunakan dan menyimpan kembali.

Implikasi terhadap pemilihan metode harus sesuai dengan karakteristik pembelajaran tematik, maka dalam pembelajaran yang dilakukan perlu disiapkan berbagai variasi kegiatan dengan menggunakan multi metode.

Pembelajaran tematik memerlukan guru yang baik dalam menyiapkan kegiatan/pengalaman belajar bagi siswa, juga dalam memilih kompetensi dan mengaturnya agar pembelajaran menjadi lebih bermakna, menarik, menyenangkan, dan utuh. Menurut Papas (1990:39) "Untuk melaksanakan pembelajaran tematik guru dapat memilih topik. Pemilihan topik dalam pembelajaran tematik mempunyai 
keuntungan untuk mengetahui individu siswa di dalam kelas." Pembelajaran tematik dapat juga mengambarkan siswa dengan banyak pilihan tentang bagaimana cara mengikuti mereka belajar.

Tidak ada cara satupun yang tepat untuk mengembangkan atau merencanakan pembelajaran tematik. Ada metode-metode untuk merencanakan yang bisa disesuaikan untuk pribadi guru, siswa, dan kelas. Metode-metode ini adalah pedoman, saran untuk memperbaiki dan meningkatkan pembelajaran. Topik untuk pembelajaran tematik bisa dipilih dengan berbagai cara. Guru harus bisa mengembangkan isi kurikulum, bagaimanapun pikiran siswa saat belajar, perencanaannya disesuaikan dengan minat siswa. Guru bisa memulai dengan penuh tanggung jawab untuk memilh tema dan kemudian membiarkan siswa aktif dalam perencanaan, bahkan dari semula berikan suatu jalan dimana guru bisa menghubungkan konsep untuk mengajar dan sifat alamiah siswa yaitu kegembiraan dan kecurigaan dunia sekitarnya, sebagai contoh: Seorang guru kelas I SD menemukan pada hari pertama sekolah, salah satu dari siswa membawa sebuah kerang laut yang indah dari perjalanannya untuk ditunjukan ke kelas. Sehingga siswa lain menjadi terpesona karena belum pernah melihat, maka guru dapat memulai pembelajaran dengan tema laut, suatu tema yang sudah atau belum direncanakan sebelumnya.

Dalam memilih suatu tema, pilihlah salah satu yang mencakup materi yang sangat luas, tetapi tidak terlalu sangat diperlukan untuk beberapa tingkat kelas.
Jadi pembelajaran tematik lebih menekankan pada penerapan konsep belajar sambil melakukan sesuatu (learning to by). Oleh karena itu, guru perlu mengemas atau merancang pengalaman belajar yang akan mempengaruhi kebermaknaan belajar siswa. Dengan penerapan pembelajaran tematik di sekolah dasar akan sangat membantu siswa, karena sesuai dengan tahap perkembangannya siswa yang masih melihat segala sesuatu sebagai satu keutuhan (holistik). Penilaian dalam pembelajaran tematik adalah suatu usaha untuk mendapatkan berbagai informasi secara berkala, berkesinambungan, dan menyeluruh tentang proses dan hasil dari pertumbuhan dan perkembangan yang telah tercapai oleh siswa melalui program proses belajar.

Tujuan penilaian pembelajaran tematik adalah: (1) mengetahui percapaian indikator yang telah ditetapkan; (2) memperoleh umpan balik bagi guru, mengetahui hambatan yang terjadi dalam pembelajaran maupun efektivitas pembelajaran; memperoleh gambaran yang jelas tentang perkembangan pengetahuan, keterampilan dan sikap siswa; (4) sebagai acuan dalam menentukan rencana tindak lanjut.

Alat penilaian dapat berupa tes dan non tes. Tes mencakup: tertulis, lisan, atau perbuatan catatan harian perkembangan siswa, dan forto folio. Dalam kegiatan pembelajaran di kelas rendah penilaian yang lebih banyak digunakan adalah melalui pengamatan yang lalu dicatat pada sebuah buku bantu. Sedangkan tes tertulis digunakan untuk menilai kemampuan menulis 
siswa, khususnya untuk mengetahui tentang penggunaan tanda baca, ejaan, kata atau angka.

\section{METODE PENELITIAN}

Pendekatan yang digunakan dalam penelitian ini berupa pendekatan kualitatif dan kuantitatif. Pendekatan ini berkenaan dengan perbaikan atau peningkatan hasil proses pembelajaran dan hasil pada suatu kelas. Jenis penelitian yang dilakukan merupakan penelitian tindakan kelas.

Pengumpulan data dilakukan melalu teknik observasi, wawancara, dan dokumentasi. Alat pengumpulan data yang akan digunakan adalah Lembar Instrumen Peneilaian Kemampuan Guru yang digunakan untuk mengamati rencana pelaksanaan pembelajaran yang berhubungan dengan RPP yang sesuai dengan pendekatan lingkungan. Lembar observasi, berupa lembaran pengamatan yang di sediakan untuk mengamati proses penggunaan pendekatan lingkungan untuk meningkatkan proses pembelajaran tematik pada siswa di kelas I SD Negeri 05 Malabur Kecamatan Ampek Nagari Basung Kabupaten Agam. Dokumentasi, dilakukan pada saat kegiatan pebelajaran berlangsung. Dokumentasi digunakan untuk mengabdikan kegiatan-kegiatan penting. Sedangkan model analisis data kuantitatif ini dilakukan terhadap hasil belajar siswa dengan menggunakan teknik persentase yang diungkapkan Kunandar (2009:96) dengan rumus sebagai berikut:

$$
\text { Skor }=\frac{\text { Jumlah Skor Yang diperoleh }}{\text { Jumlah Skor Maksimal }} \times 100 \%
$$

\section{HASIL DAN PEMBAHASAN}

Pengamatan terhadap tindakan pembelajaran tema dilakukan bersamaan dengan pelaksanaan tindakan. Hal ini dilaksanakan secara intensif, objektif, dan sistimatis. Pengamatan akan dilakukan oleh teman sejawat selaku obsever pada waktu peneliti melaksanakan tindakan pembelajaran tematik. Dalam kegiatan ini peneliti dan teman sejawat berusaha mengenal, dan mendokumentasikan semua indikator dari proses hasil perubahan yang telah terjadi, baik yang disebabkan oleh tindakan terencana maupun intervensi dalam pembelajaran. Keseluruhan hasil pengamatan ditulis dalam lembar observasi. Pengamatan akan dilakukan secara terus menerus. Pengamatan yang dilakukan pada satu siklus dapat mempengaruhi penyusunan tindakan pada siklus selanjutnya. Hasil pengamatan ini kemudian didiskusikan dengan teman sejawat dan diadakan refleksi untuk perencanaan siklus berikutnya. Obsever mengevaluasi sejauh mana tindakan yang telah dilakukan dalam memecahkan masalah dengan melihat:

1. Menyusun langkah-langkah perbaikan pembelajaran.

2. Menentukan alokasi wakktu dalam perbaikan pembelajaran

3. Menggunakan bahan atau media perbaikan pembelajaran dan merumuskan tujuan pembelajaran

4. Menentukan cara pengorganisasian siswa agar siswa dapat berpartisipasi dalam perbaikan pembelajaran 
5. Melaksanakan pembelajaran yang sesuai dengan tujuan, siswa, situasi dan lingkungan

6. Melaksanakan perbaikan secara individual

7. Member petunjuk dan penjelasan yang berkaitan dengan tema pembelajaran

8. Mendemontrasikan penguasaan materi Bahasa Indonesia

9. Mengembangkan siswa untuk berkomunikasi dan bernalar
10. Memberikan latihan keterampilan berbahasa khususnya dalam membaca

11. Peka terhadap kesalahan lafal dan intonasi dalam membaca siswa

12. Memupuk kegemaran membaca

13. Melaksanakan penilaian selama proses pembelajaran

14. Melaksanakan penilaian pada akhir pembelajaran

15. Penggunaan Bahasa Indonesia lisan

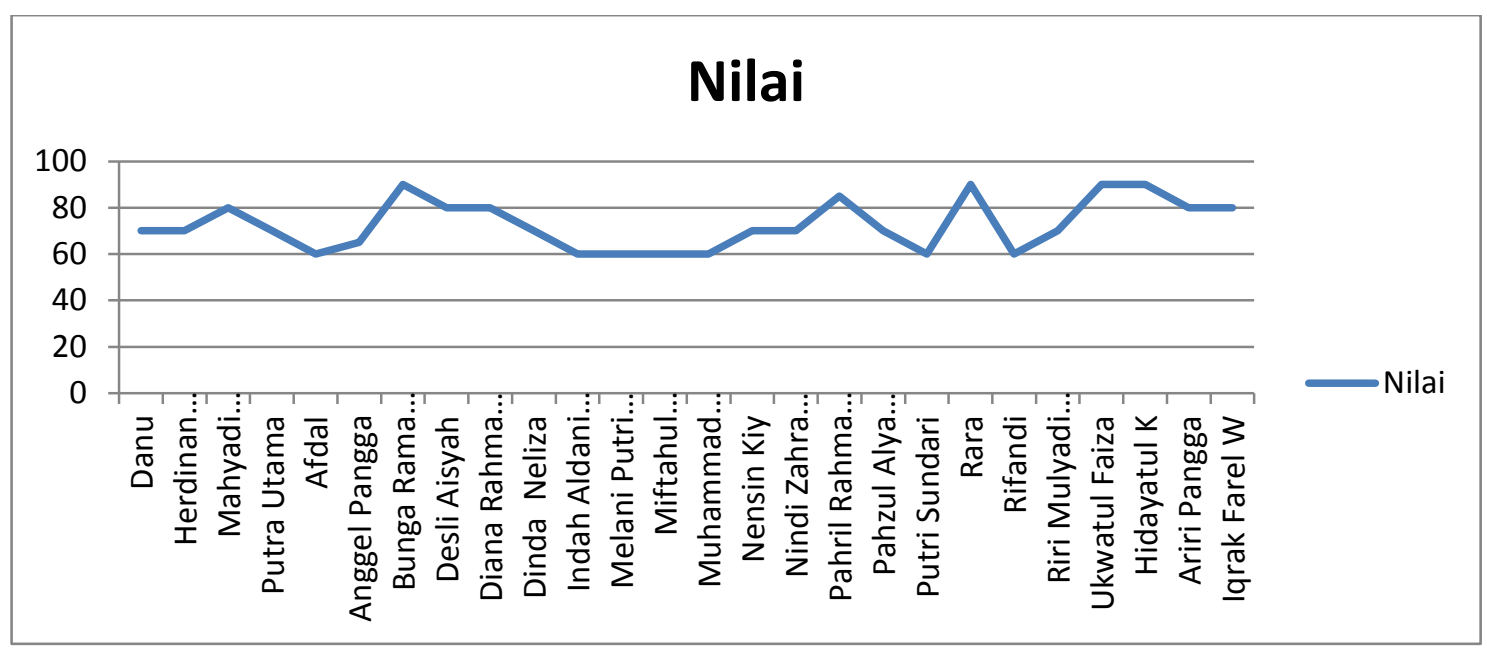

Gambar 1 Hasil Belajar Siswa Siklus I

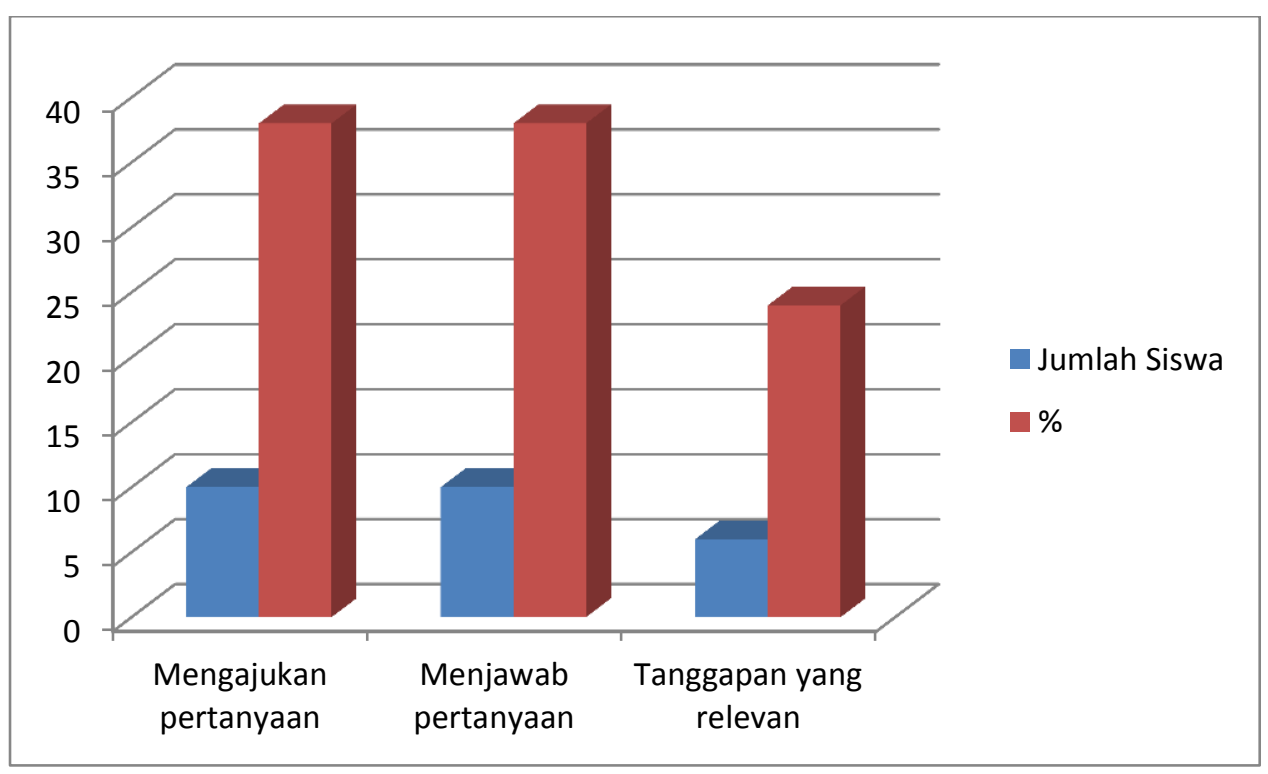

Gambar 2 Aktivitas Belajar Siswa Pada Siklus I 
Berdasarkan pengamatan dan catatan yang dilakukan oleh peneliti dengan teman sejawat dari pelaksanaan kegiatan pembelajaran pada siklus I dapat digambarkan hasil tes proses dan tes akhir.

Refleksi pada siklus I berdasarkan pengalaman dan instrumen penelitian pada kenyataannya dalam proses pembelajaran yang diperoleh bahwa tujuan pembelajaran yang kita inginkan belum tercapai. Guru sebagai fasilitator belum mampu membuat siswa aktif untuk mengajukan pertanyaan, menjawab pertanyaan dan menanggapi dalam pembelajaran ini. Sehingga cara belajar siswa belum tampak perubahan yang berarti. Pemakaian waktu yang belum efektif dan efisien belum bisa diatasi sehingga dalam pembelajaran waktu tidak mencukupi. Untuk meningkatkan hasil yang baik dan bagus maka penelitian dilanjutkan pada siklus II. Pada siklus II siswa belajar pembelajaran tematik yang berfokus pada pembelajaran Bahasa Indonesia dalam keterampilan membaca. Masingmasing siswa di bimbing langsung dalam membaca teks bacaan dengan lafal dan intonasi yang tepat. Pengamatan akan dilakukan secara terus menerus mulai dari siklus 1 sampai siklus II. Pengamatan yang dilakukan pada satu siklus dapat mempengaruhi penyusunan tindakan pada siklus selanjutnya. Hasil pengamatan ini kemudian didiskusikan dengan teman sejawat dan diadakan refleksi untuk perencanaan siklus berikutnya. Obsever mengevakuasi sejauh mana tindakan yang telah dilakukan dalam memecahkan masalah.
Perbedaan Hasil belajar siklus I dan II dapat dilihat pada Gambar 3.

Pada siklus I dilakukan pengamatan oleh teman sejawat pada guru dan siswa yang sedang melaksanakan proses pembelajaran. Guru sudah melaksanakan pembelajaran tematik namun siswa belum aktif mengikutinya sehingga beberapa siswa yang disuruh membaca teks bacaan lafal dan intonasinnya belum begitu tepat. Pada saat pembelajaran berlangsung pun siswa kurang aktif untuk bertanya, mengajukan pertanyaan serta menanggapinya. Pada akhir pembelajaran guru menjelaskan pelajaran yang menyangkut tema yang dipelajari dan mencontohkan cara membaca dengan lafal dan intonasi yang tepat, serta memberi contoh cara menjawab, mengajukan pertanyyan serta menanggapinya. Siswa mendengarkan penjelasan guru dengan senang dan penuh semangat.

Pada siklus II ini proses pembelajaran tematik masih dilakukan pengamatan oleh teman sejawat pada peneliti sebagai guru kelas dengan siswa dalam melaksanakan pembelajaran. Pembelajaran tematik berlangsung dengan baik, siswa pun lebih aktif dan bersemangat pada saat masing-masing siswa disuruh membaca teks bacaan ke depan kelas. Pada saat masing-masing siswa disuruh membaca ke depan kelas siswa lebih aktif dan lebih bersemangat lagi dan dalam membaca teks bacaan lafal dan intonasinya sudah banyak yang tepat. Dalam proses pembelajaran berlangsung sudah banyak siswa yang bertanya, yang mengajukan pertanyaan dan bahkan ada yang menanggapinya. 


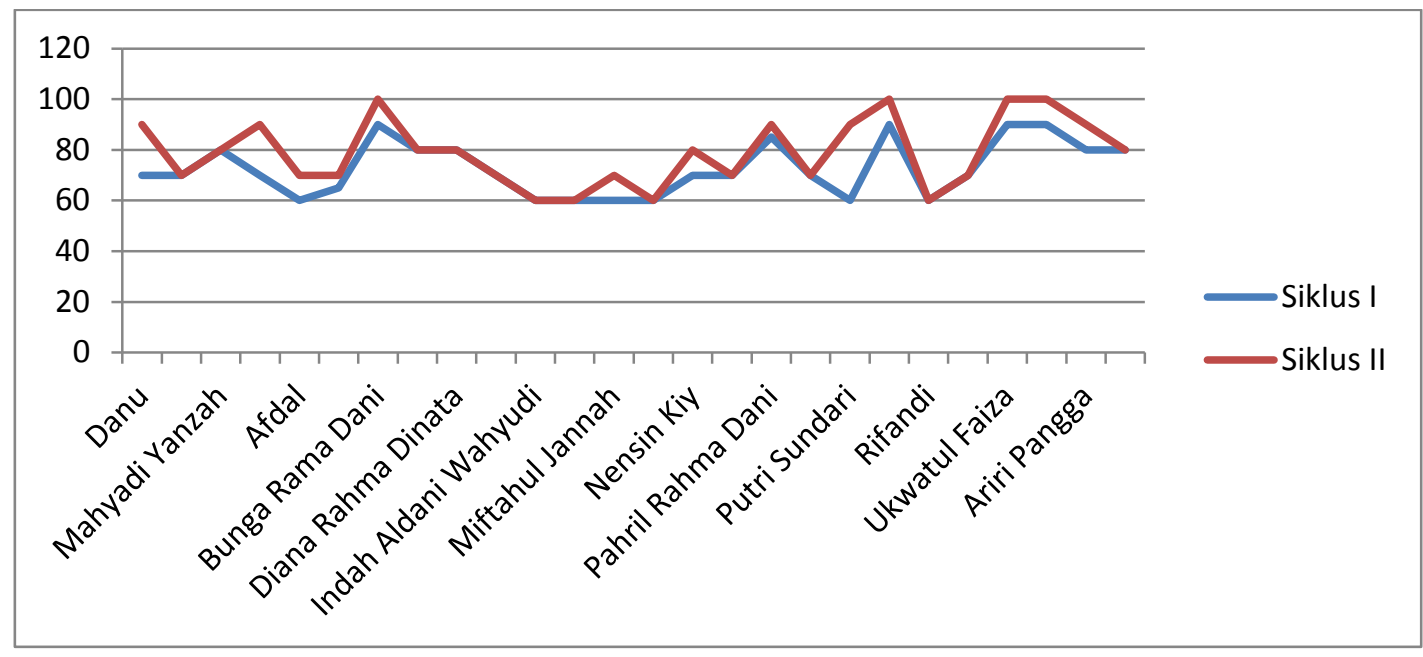

Gambar 3 Hasil Belajar Siswa Pada Siklus I dan Siklus II

Pada siklus II ini banyak sekali perubahan dan penigkatan yang signitif dari proses pengajaran guru dan proses pembelajaran dari siswa sehingga dapat dilihat nilai persentasi dari ketuntasan anak yang mencapai 78.8, sedangkan pada siklus I persentasi ketuntasan anak hanya mencapai 72.6 .

\section{PENUTUP}

Berdasarkan kesimpulan yang telah diperoleh dalam penelitian ini, maka disarankan dalam merancang pelaksanaan perbaikan pembelajaran dalam pembelajaran tematik kita harus mengetahui apa yang di maksud dengan pendekatan tematik. Dalam pembelajaran tematik kita beranjak dari tema dan semua pembelajaran terpadu dalam satu tema tersebut. Kita harus melihat situasi dan kondisi siswa dan lingkungan belajar serta lingkungan kesehari-harian anak. Dalam proses pembelajaran tematik dapat meningkatkan keterampilan berbahasa siswa dalam membaca dengan lafal dan intonasi yang tepat.

\section{UCAPAN TERIMA KASIH}

Penelitian ini terlaksana karena adanya kerjasama pihak SD Negeri 05 Malabur Kecamatan Ampek Nagari dengan UPT Dinas Pendidikan Kecamatan Lubuk Basung yang telah memfasilitasi dan membantu untuk kelancaran penyelesaikan penelitian ini.

\section{DAFTAR PUSTAKA}

Abbas, Saleh. (2006). Bahasa Indonesia Yang Efektif Di Sekolah dasar.Jakarta : Depdikbud.

Agung, Arman. (2008). keterampilan Berbicara Rhetorika dan Berbicara Efektif. (http:/www. bpplsp-reg5.go.id/download/ket bicara.doc download tanggal 11/03/2008/13:50).

Akhadiah, Subarti. (1991). Bahasa Indonesia I. Jakarta:Depdikbud

Depdikbud. (1993). Kurikulum Pendidikan Dasar. Jakarta : Depdikbud. 
Depdiknas. (2006). Badan Standar Nasional Pendidikan. Jakarta : BSNP.

Depdiknas. (2006). Kurikulum Tingkat Satuan Pendidikan. Jakarta : Erlangga.

Darsono. (2001). Pembelajaran khusus berdasarkan aliran psikologi.

Karli, Hilda. (2006). Panduan Belajar Tematik. Bandung: Erlangga.

Mundilarto, Rustam. (2004). Penelitian Tindakan Kelas. Jakarta: Depdiknas
Santosa, Puji. (2004). Materi dan Pembelajaran Bahasa Indonesia. Padang: Universitas Terbuka.

Tarigan, Hendry Guntur. (1986). Menulis Sebagai Suatu Keterampilan Berbahasa. Bandung : Angkasa.

Zainuddin. (1992). Materi Pokok Bahasa dan sastra Indonesia. Jakarta:Rineka 